\title{
Chondrocranial and hyobranchial structure in two South American suctorial tadpoles of the genus Telmatobufo (Anura: Calyptocephalellidae)
}

\author{
J. Ramón Formas ${ }^{1}$ and César C. Cuevas ${ }^{1,2}$ \\ ${ }^{1}$ Laboratorio de Sistemática, Instituto de Ciencias Marinas y Limnológicas, Universidad Austral de Chile. Valdivia, Chile. \\ E-mail: rformas@uach.cl. \\ ${ }^{2}$ Departamento de Ciencias Biológicas y Químicas, Universidad Católica de Temuco. Chile. E-mail: cesar.cuevas@uct.cl.
}

\begin{abstract}
Chondrocranial and hyobranchial structure in two South American suctorial tadpoles of the genus Telmatobufo (Anura: Calyptocephalellidae). The chondrocranium, hyobranchium, rectus abdominis muscle, and epaxial musculature of Telmatobufo australis and T. ignotus are described. In addition, these structures were compared wih those of the non-suctorial Calyptocephalella gayi, the sister group of Telmatobufo.
\end{abstract}

Keywords: Evolution, larval morphology, southern Chile, suctorial tadpoles.

\begin{abstract}
Resumen
Estructura del condrocráneo y aparato hiobranquial de dos renacuajos suctores sudamericanos del género Telmatobufo (Anura: Calyptocephallidae). Se describen los condrocráneos, aparatos hiobranquiales, músculo recto abdominal, y la musculatura epaxial de Telmabufo australis y $T$. ignotus. En adición, los renacuajos de Telmatobufo se comparan con los de Calyptocephalella gayi, el grupo hermano de Telmatobufo.
\end{abstract}

Palabras claves: evolución, morfología larvaria, renacuajos suctores, sur de Chile.

\section{Resumo}

Estrutura do condrocrânio e do aparelho hiobranquial de dois girinos suctoriais sulamericanos do gênero Telmatobufo (Anura: Calyptocephalellidae). Descrevemos aqui o condrocrânio, o aparelho hiobranquial, o músculo reto-abdominal e a musculatura epiaxial de Telmabufo australis e T. ignotus. Além disso, comparamos os girinos de Telmatobufo aos de Calyptocephalella gayi, o grupo-irmão de Telmatobufo.

Palavras-chave: evolução, girinos suctoriais, morfologia larval, sul do Chile.

Received 29 October 2019

Accepted 26 May 2020

Distributed June 2020 


\section{Introduction}

Anurans of the family Calyptocephalellidae (genera Telmatobufo Schmidt, 1952 and Calyptocephalella Strand, 1928) are a small, old Gondwanan lineage (Clade Australobatrachoidea; San Mauro et al. 2005) that inhabits lentic (Calyptocephalella) and lotic (Telmatobufo) environments associated with the trans-Andean temperate Nothofagus forests of South America. Pyron and Wiens (2011) suggested that Telmatobufo and Calyptocephalella are sister groups that probably diverged during the Oligocene-Miocene in southern South America (Nuñez and Formas 2000, Frazão et al. 2015). The species of Telmatobufo-T. australis Formas, 1972 (Formas 1972) (Figure 1 A, B), T. bullocki Schmidt, 1952 (Formas 1988), T. venustus (Philippi, 1899) (Díaz et al. 1983), and T. ignotus Cuevas, 2010 (Cuevas 2010) (Figure $1 \mathrm{C}, \mathrm{D})$ - have a characteristic larval ecomorphotype. It is a mountain stream-type with a highly modified suctorial oral disc, robust and depressed body, well-developed tail muscles, and low tail fins. The pond-type tadpoles of Calyptocephalella gayi (Duméril and Bibron, 1841) differ from those of Telmatobufo in having anteroventral non-suctorial mouth, normal development of tail musculature, and moderatesized caudal fins (Cei 1962) (Figure 1 E, F). Herein, we describe the chondrocranium, hyobranchial apparatus, epaxial musculature, and rectus abdominis muscle of Telmatobufo australis and T. ignotus. We compare the morphology of these species with that of the sister species Calyptocephalella gayi, and comment on the evolution of the tadpoles of Telmatobufo.

\section{Materials and Methods}

Twelve tadpoles of the following species were examined: Telmatobufo australis $(N=6$, IZUA-3652), $T$. ignotus $(N=4$, IZUA-3653) and Calyptocephalella gayi $(N=3$, IZUA-

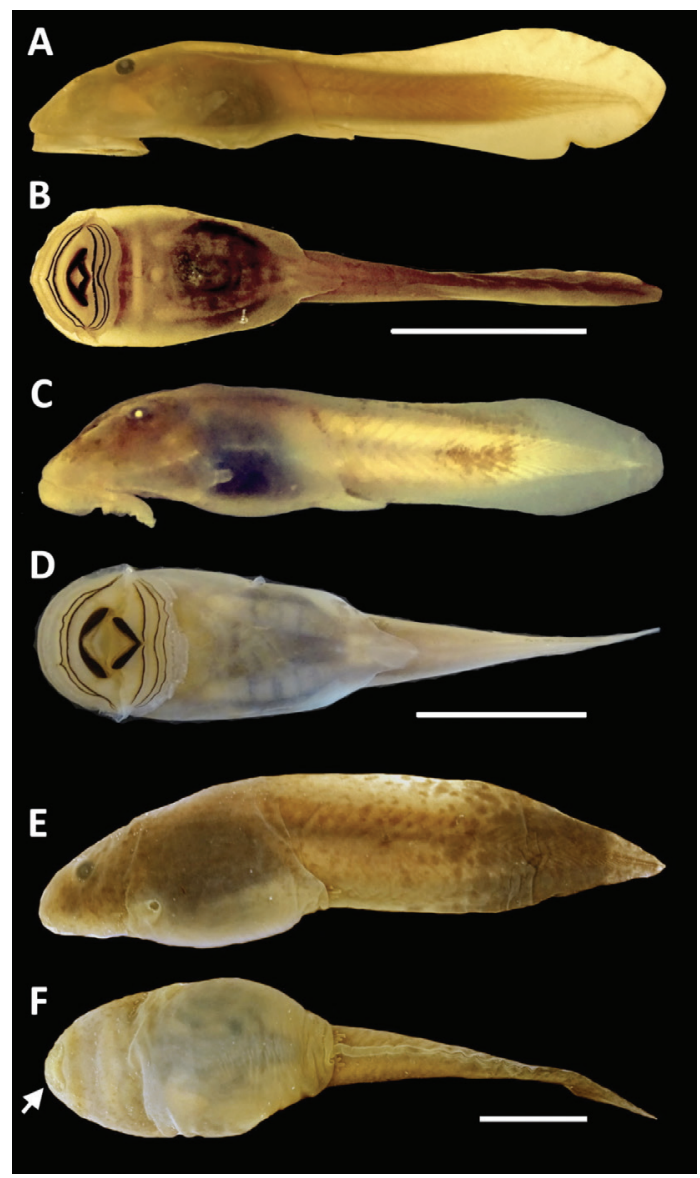

Figure 1. Tadpoles (Stage 30; lateral and ventral views) of Telmatobufo australis (A, B), T. ignotus (C, D) and Calyptocephalella gayi $(\mathbf{E}, \mathbf{F})$. The arrow indicates the mouth of $C$. gayi. Bar $=20$ $\mathrm{mm}$.

3656). Following the Song and Parenti (1995) technique, we stained and cleared the chondrocranium and the hyobranchial apparatus of four tadpoles of $T$. australis (Stage 30), three T. ignotus (Stage 31), and one C. gayi (Stage 30). We performed manual dissections to examine the rectus abdominis and epaxial muscles of two tadpoles of T. australis (Stage 30), one T. ignotus (Stage 31) and one C. gayi (Stage 33). 
The tadpoles of Telmatobufo australis were collected in February 1972 in a small stream in secondary forest of the coastal mountain range at Chivería (3957'79" S, 73²8'52" W), Valdivia Province in southern Chile. The larvae of $T$. ignotus were collected in December 2007 in a stream located in a remnant of Maulino Forest in the coastal mountain range at Ramadillas Ravine (35॰56'57” S, 72³6'57" W), Cauquenes Province in central Chile. The tadpoles of Calyptocephalella gayi were collected in January 2004 in a permanent lagoon in the city of Valdivia (3949'28" S, 73¹3'26" W), Valdivia Province in southern Chile.

The tadpoles were euthanized following strict biosafety protocols, staged according Gosner (1960), and cleared and stained. The adopted the terminology of chondrocranial morphology of Larson and de Sá (1998).

The myological terminology follows that of Haas and Richars (1998), and the rectus abdominis muscle is described in the manner of Carr and Altig (1992). The larvae examined are housed in the Laboratorio de Sistemática, Instituto de Ciencias Marinas y Limnológicas, Universidad Austral de Chile.

\section{Results}

\section{Chondrocranium}

The chondrocranium and hyobranchial apparatus of larvae of Telmatobufo ignotus and T. australis are morphologically similar. Thus, the following description is based on T. australis; features that differ in T. ignotus are described parenthetically. These differences should be considered with caution and confirmed by examination of more extensive samples. At Stage 30 , the chondrocranium is open dorsally and $1.3 \times$ longer than wide. The maximum width, at the level of the anterior edge of the pars articularis quadrati, is $79 \%$ of the total length of the chondrocranium. The maximum height at the level of the processus muscularis is about $35 \%$ of the length.

\section{Neurocranium}

The length of the trabecular horns of Telmatobufo australis is about $32 \%$ of the chondrocranial length (Figure 2A). The anterior third of each horn is expanded and diverges laterally from its counterpart; the expansion is about $3 \times$ the width of the horn at the level of the bifurcation. According to Haas (2003), the cornu trabeculae proportion (ratio of the width of the cornua at their base divided by their length) is 0.85 . Accordingly, the trabecular horns have an extensive transverse articulation with the dorsal margin of the suprarostral cartilage (Figure 2B). The short and pointed lateral process lies at the base of each horn and receives a well-developed ligamentum quadratoethmoidale from the quadratoethmoid process of the quadratocranial commisure. The olfactory foramen is well defined. The frontoparietal fenestra occupies the $57 \%$ of the length of the chondrocranium. The lateral walls of the braincase are formed by the orbital cartilages. The prootic foramen, large and elongate, is located between the anterior edge of the otic capsule and the posterior margin of the orbital cartilage. Two other large foramina are visible in the posteroventral portion of the orbital cartilage. The smallest is posterior to the oculomotor foramen and the anterior edge of the optic foramen. The pila metoptica separates the foramina. The pila antotica lies between the oculomotor foramen and the anterior edge of the prootic foramen. The oculomotor foramen is rounded and its diameter is less than the oval optic foramen. The subocular fenestra is elongate (round in $T$. ignotus) and approximately onesixth the length of the chondrocranium. The commisura quadratocranialis anterior is onethird the length of the chondrocranium and $1.5 \times$ the maximum width of the otic capsule. Dorsally, the otic capsules are rhomboid with the maximum dimension being $1.2 \times$ greater than the width as measured at a right angle to the axial axis; the greatest dimension of the capsule is about $23 \%$ of the chondrocranial length. There are three semicircular canals: the anterior and the lateral 
are well defined, but the posterior is diffuse. The otic capsules are connected dorsally via the tectum synoticum; ventrally, they contact the basicranial floor. The fenestra ovalis is small, located in the ventrolateral wall of the otic capsule. The occipital arch forms the posterior part of the chondrocranium. The ventral occipital condyles are oriented laterally; they are slightly pedunculate and separated by the notochordal canal. The jugular foramen is near the ventral region of the occipital arch and the otic capsule. The suprarostral cartilage supports the upper jaw. In T. australis, it consists of a medial corpus and two lateral alae (Figure 2B). The pars corporis and the pars alaris are arranged in an arched line that bears the jaw sheath. The cornu trabeculae has a wide synchondrotic articulation of a flexible cartilage with suprarostral cartilage. The partes corporis of the suprarostral cartilage are broadly fused in a large plate about $7 \times$ wider than high. The height of the suprarostral plate is uniform; however, its medial portion deviates ventrally, as indicated by the concave dorsal margin. Both the pars corporis plate and the pars alaris are broadly fused. The pars corporis is almost perpendicular to axis the body. The pars alaris is positioned laterally to the sagittal axis of the body and concentric to the pars corporis. The posterior process of the pars alaris is single, with a rounded distal tip and dorsal orientation. The adrostral cartilages are large and elongate and parasagittally oriented. They are close to the suprarostral cartilage (pars alaris), but are not in contact; a thin rod of cartilaginous tissue separates them.

\section{Visceral Components}

Palatoquadrate.-The long and markedly broad palatoquadrate lies parallel to the longitudinal body axis (Figure 2A). The pars articularis quadrati is expanded anteriorly and has three well-defined processes on the anterior margin. The lateral circumoral ligament extends from the tip of the trabecular horns to the anterolateral margins of the partes articularis
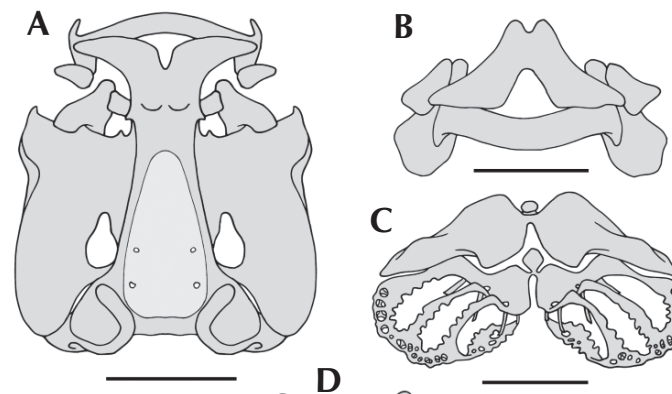

D
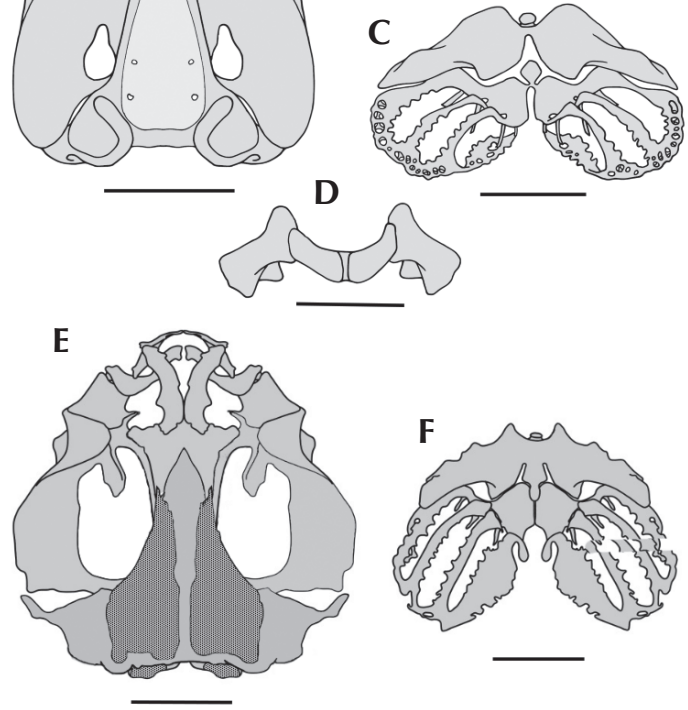

Figure 2. Chondrocranium and hyobranchial apparatus of Telmatobufo australis (Stage 30). Dorsal view of the chondrocranium and mandibular arch (A), frontal view of the lower jaw and suprarostral (B), ventral view of the hyobranchial apparatus (C), and ventral view of the lower jaw (D). Dorsal view of the chondrocanium and mandibular $\operatorname{arch}(\mathbf{E}, \mathbf{F})$ and ventral view of the hyobranchial apparatus of Calyptocephalella gayi (Stage 33). The dotted area (E) indicates the ossification of the frontoparietal, parasphenoid, and exooccipital bones. Bar $=5 \mathrm{~mm}$.

quadrati. The processus muscularis quadrati is triangular and broad; it is pointed in lateral view, rounded dorsally, inclined medially, and does not exceed the height of the chondrocranium. The ligamentum tectum attaches the muscular process of the palatoquadrate to the anterior end of the processus anteorbitalis. Posteriorly, the palatoquadrate attaches to the orbital cartilage via the process ascendens. This narrow, thin cartilage contacts the pila antotica at the level of 
the oculomotor foramen ("intermediate" level of attachment; Sokol 1981) and it is located obliquely to the longitudinal axis of the chondrocranium oblique to the central axis of the chondrocranium.

Meckel's cartilage and cartilage labialis inferioris.-Meckel's cartilage is broad, robust, and sigmoid in shape; it is about $27 \%$ of the chondrocranium length (Figure 2D). The cartilage is oblique to the medial axis of the chondrocranium, forming an angle of nearly $45^{\circ}$. It articulates with the infrarostral cartilage rostrally and with the pars articularis quadrati caudall; the latter articulation is saddle-shaped. The anterior and posterior margins of the paired infrarostral cartilages are slightly curved and broader medially than laterally; medially they are connected by a syndesmotic commissura intermandibularis.

\section{Hyobranchial Apparatus}

The hyobranchial apparatus of Telmatobufo australis is composed of the ceratohyals and the branchial baskets (Figure 2C). The subrectangular, wide, and flattened ceratohyals are medially connected by a cartilaginous pars reuniens. A small basihyal lies anterior to the pars reuniens. Each ceratohyal bears a rounded anterior process and a pointed and divergent posterior process. The anterolateral process is not evident. The process lateralis is elongate and its distal end is rounded (acuminate in $T$. ignotus). The basibranchial is rhomboidal and bears a rounded, posteriorly directed urobranchial process. The subtriangular hypobranchial plate forms a well-defined hypobranchial sinus. The branchial baskets consist of four curved ceratobranchials distally joined via commissure terminals. Ceratobranchials I-IV are fused with the hypobranchial plate. The proximal end of the Ceratobranchial I is contiguous with the hypobranchial plate and has a pointed processus anterior brachialis, similar to the branchial processes that the remainder ceratobranchials bear. Ceratobranchials I-III are curved and bear lateral projections, except for the inner side of Ceratobranchial III. The short, broad Ceratobranchial IV is fused to the hypobranchial plate. There are three curved spicules (I-III) that are about $25 \%$ of the length the respective ceratobranchial. The distal tips of Spicules I and III are truncate, whereas that of Spicule II is bifurcate. Spicule IV is not evident.

\section{Musculature}

The epaxial postcranial musculature is well developed and extends over the otic capsule to insert on the anterior third of the capsule. The rectus abdominis muscle reaches the anterior end of the ceratohyals. The muscle consists of two thin, well-defined bands composed of seven myotomes that diverge anteriorly. The medial aponeurosis between both bands is ample-i.e., at the level of the fifth myotome the area corresponds to a sixth the length of the muscle and a quarter at the level of the first myotome. The gut coils are visible through the aponeurosis. Myotomes 2-7 are quadrangular, and the most anterior is conical. The length of the myotomes increases from back to front; the most anterior myotome is approximately $1.7 \times$ than the seventh. All myotomes have densely packed fibers. (In $T$. ignotus, the rectus abdominis is more extensive and robust than in T. australis).

\section{Discussion}

Haas and Richards (1998) concluded that the morphological specializations of suctorial tadpoles result from convergent evolution of external and internal characters (e.g., oral suctorial disc, robust and depressed body, active tail muscle and low tail fins, fusion of the suprarostrals, expanded trabecular horns, robust infrarostrals, and palatoquadrate).

Phylogenetically, Pyron and Wiens (2011) suggested that the genera Telmatobufo and Calyptocephalella (Calyptocephallidae) are sister groups. However, the taxa differ 
osteologically (e.g., atlas and axis fused in Telmatobufo; cranium heavily ossified in Calyptocephalella; Lynch 1978), as well as in external larval morphology; Telmatobufo has suctorial tadpoles, whereas Calyptocephalella gayi has generalized, pond-type larvae (Orton 1953). The differences in the external and internal characters of the tadpoles of Telmatobufo ( $T$. australis, T. ignotus) and Calyptocephalella gayi (Figure 2E, F) are summarized in Table 1. These foregoing distinctions suggest that there may have been divergent evolutionary trajectories acting on the adult and larval frogs. In the case of larval Telmatobufo, evolution produced novelties (i.e., synapomorphies) that distinguish the genus. During the Miocene-Oligocene, southern South America underwent significant orogenic changes, characterized mainly by the Andean uplift (Dott et al. 1977). The Andes acted as a barrier to wind circulation (Westerlies), causing a rain shadow that led to increased desertification east of the Andes (Ruzzante and Rabassa 2011).

Phylogenetically, it seems evident that the common ancestor of Calyptocephalella and Telmatobufo probablywas an anuran that was not hyperossified and that had a generalized, pondtype larvae. We postulate that members of this anuran clade (i.e., the ancestor and all of its descendants; Wiley and Lieberman 2011) diverged from one another during the MioceneOligocene when the Andes were being uplifted. The ancestor of Calyptocephalella may have been isolated east of the Andes, where some species disappeared (e.g., Calyptocephalella spp.; Muzzopappa and Báez 2009, Agnolin 2012) and others adapted to the xeric conditions, giving rise to species, such as the hyperossified C. gayi that retains a generalized larval type. In contrast, the ancestral lineage leading to Telmatobufo seems to have evolved a specialized suctorial larva as an adaptation to the lotic environments that became available along the southwestern edge of Gondwana with the uplift of the Andes in what today is southern Chile. The particular suite of evolutionary novelties shared by the tadpoles of Telmatobufo is unique among australobatrachian anurans; it defines the genus taxonomically and supports its monophyly.

\section{Acknowledgments}

Our special thanks to Florencia Vera-Candioti who reviewed and improved the first drafts. The comments and suggestions of Linda Trueb and an anonymous referee substantially improved the final manuscript. Valentín Peña, technician of the Institute of Embryology, provided the tadpoles of T. australis and Marcos Navarro prepared the illustrations.

\section{References}

Agnolin, F. 2012. A new Calyptocephalellidae (Anura, Neobatrachia) from the Upper Cretaceous of Patagonia, Argentina, with comments on its systematic position. Studia Geologica Salmanticensia 48: 129-178.

Carr, K. and R. Altig. 1992. Configurations of the rectus abdominis muscle of anuran tadpoles. Journal of Morphology 214: 351-356.

Cei, J. M. 1962. Batracios de Chile. Santiago. Ediciones de la Universidad de Chile. 128 pp.

Cuevas, C. C. 2010. A new species of Telmatobufo Schmidt 1952 (Anura, Calyptocephallidae) from a remnant of Maulino Forest, central Chile. Gayana 74: 102-112.

Díaz, N., M. Salaberry, and H. Nuñez. 1983. The tadpole of Telmatobufo venustus (Anura: Leptodactylidae) with consideration of generic relationships. Herpetologica 39: $111-113$

Dott, R. H., R. D. Winn, M. L. Dewitt, and R. L. Bruhn. 1977. Tectonic and sedimentary significance of the Cretaceous Tekerika beds of Tierra del Fuego. Nature 266: 620-622.

Formas, J. R. 1972. A second species of the genus Telmatobufo (Anura: Leptodactylidae). Journal of Herpetology 6: 1-3.

Formas, J. R. 1988. The tadpole of Telmatobufo bullocki (Anura: Leptodactylidae). Herpetologica 44: 45-60.

Frazão, A., H. R. Silva, and C. A. M. Russo. 2015. The Gondwana breakup and the history of the Atlantic and Indian oceans unveils two new clades for early neobatrachian diversification. PLOS ONE 10: e043926. 

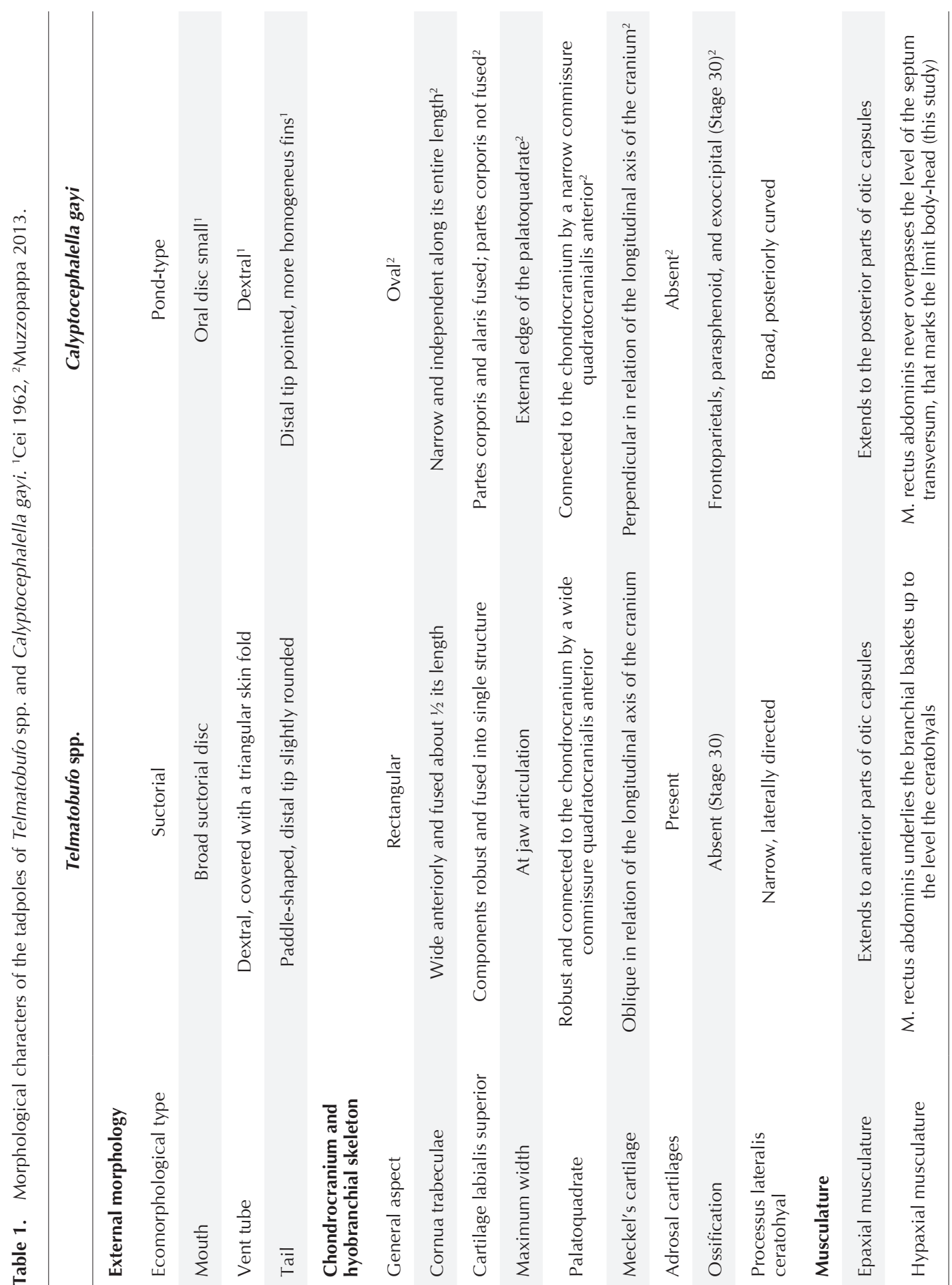
Gosner, K. L. 1960. A simplified table for staging anuran embryos and larvae with notes on identification. Herpetologica 16: 183-190.

Haas, A. 2003. Phylogeny of frogs as inferred from primarily larval characters (Amphibia: Anura). Cladistics 19: 2389.

Haas, A. and S. Richards. 1998. Correlations of cranial morphology, morphology, and evolution in Australian of the genera Lithoria and Nyctimystes (Amphibia: Anura: Hylidae: Pelodryadinae). Journal of Morphology 238: 109-141.

Larson, P. M. and R. O. de Sá. 1998. Chondrocranial morphology of the Leptodactylus larvae (Leptodactylidae: Leptodactilinae): its utility in phylogenetic reconstruction. Journal of Morphology 238: 91-102.

Lynch, J. D. 1978. A re-assessment of the telmatobiine leptodactylid frogs of Patagonia. Occasional Papers of the Museum of Natural History, University of Kansas 72: $1-57$.

Muzzopappa, P. 2013. Anatomía esqueletaria y osteogenésis de Calyptocephalella gayi (Anura, Neobatrachia): aporte al conocimiento del registro fósil de un linaje gondwanico relictual. Unpublished Ph.D. Thesis. Facultad de Ciencias Exactas y Naturales. Universidad de Buenos Aires, Argentina.

Muzzopappa, P. and A. M. Báez. 2009. Systematic status of the mid-Tertiary neobatrachian frog Calyptocephalella canqueli form Patagonia (Argentina), with comments on the evolution of the genus. Ameghiniana 46: 113-125.
Nuñez, J. J. and J. R. Formas. 2000. Evolutionary history of the Chilean frog genus Telmatobufo (Leptodactylidae): an immunological approach. Amphibia-Reptilia 21: 351356.

Orton, G. 1953. The systematics of vertebrate larvae. Systematic Biology 2: 63-75.

Pyron, R. A. and J. J. Wiens. 2011. A large-scale phylogeny of Amphibia including over 2800 species, and a revised classification of extant frogs, salamanders, and caecilians. Molecular Phylogenetics and Evolution 61: $543-583$.

Ruzzante, D. E. and J. Rabassa. 2011. Paleogeography and paleoclimatology of Patagonia: effects on biodiversity. Biological Journal of the Linnean Society 103: 221228.

San Mauro, D., M. Vences, M. Alcobendas, R. Zardoya, R., and A. Meyer. 2005. Initial diversification of living amphibians predated the breakup of Pangea. American Naturalist 165: 590-599.

Sokol, O. 1981. The larval chondrocranium of Pelodystes punctatus, with a review of tadpole chondrocrania. Journal of Morphology 169: 161-183.

Song, J. and L. R. Parenti. 1995. Clearing and staining whole fish specimens for simultaneous demonstration of bone, cartilage, and nerves. Copeia 1995: 114-118.

Wiley, E. O. and B. S. Lieberman. 2011. Phylogenetics. Theory and Practice of Phylogenetic Systematics. Hoboken, New Jersey. Wiley-Backwell. 406 pp.

Editor: Vanessa Kruth Verdade 